\title{
Linking Interactive and Supportive Service Innovation with Customer Satisfaction Through Customer Value Creation
}

\author{
Bandar Khalaf Alharthey ${ }^{1}$ \\ ${ }^{1}$ Arab East Colleges, Riyadh, Saudi Arabia \\ Correspondence: Bandar Khalaf Alharthey, Department of Business Administration, P.O Box 53354, Kingdom of \\ Saudi Arabia. Tel: 966-55-909-9279.
}

Received: September 20, 2018 Accepted: October 17, 2018 Online Published: November 24, 2018

doi:10.5539/ijms.v10n4p1 URL: https://doi.org/10.5539/ijms.v10n4p108

\begin{abstract}
The main purpose of this study is to investigate the impact of service innovation (interactive and supportive) on customer satisfaction and mediating role of customer value creation. Cross sectional study is conducted in non-contrived setting and primary data is collected from the mobile users. Hypotheses are tested with a sample of 275 respondents and mediation whereas model fit is done using Smart PLS3. Results indicate that customer value creation significantly mediates the relationship between service innovation and customer satisfaction. The research is conducted on small scale and data has been collected from small geographical location (Riyadh/ Jeddah). The research would be more robust if it is conducted in other geographical area and variable (i.e. value co-creation) would be studied as mediator and customer participation as moderator. This research high lights the customer satisfaction process through value creation.
\end{abstract}

Keywords: service innovation (interactive and supportive), customer satisfaction customer value creation

\section{Introduction}

Consumers' needs wants and demands are continuously capricious which is defying for the business. Recent technological advances have brought different opportunities for all kind of businesses, including service industry (Huang, 2011). New form of technologies helps the business to offer the customer with more innovative type of services. New technologies help to create a good relationship with customers along with new ways of businesses. It also makes them able to discriminate themselves from their competitors; and create a unique selling point using new technology on the basis of which businesses are able to accelerate their competitiveness (Yeh \& Fu, 2013). Innovation is recent phenomenon which helps in the development of business and technological changes in manufacturing business. (Siltaloppi and Toivonen, 2015). Innovation phenomenon got power and position in economic development about two decades ago. This concept is now extensively used in service sector; as service innovation.

Now businesses not only focus on product development and innovation; nonetheless service innovation is also engrossed. Firms provide value added services to their customers through service innovation. (Boone, 2000). Service innovation is a blend of technological innovation and innovation in business model and social, organizational innovation. The tenacity of demand innovation is to evolve existing service system. It helps to create value and new service packages and systems (Christensen et al., 2011; Danjum and Rasli, 2012). Different scholars have focused on the different aspects of service innovation such as service delivery, service characteristics, service strategies and processes. Service delivery innovation, studied by (Chen et al., 2009). Nijssen et al. (2006) focused on characteristic and typologies of service innovation whereas process and strategies innovation in services was studied by (Alam, 2006; Chen et al., 2015). Impact of service innovation on firms' performance had been studied extensively by different scholars who studied its impact on achieving competitive advantage.

Service innovation has been classified into different categories. Past researchers have studied the innovation in service industries and categorized it into two main types; 1) radical innovation 2) incremental innovation (Johnson et al., 2000). Furthermore, other scholars have studied the other different aspects of service innovation. Few researches focused on interactive and supportive function of service innovation. In services industry it is important for service provider to interact with customers. Modern technologies have made it possible and new kinds of business models are developed. Thi TA and Yang (2018) study the relationship between service innovation and customer retention in technology intensive telecom sector through customer satisfaction. Satisfaction is important 
phenomenon in the field of marketing. To understand the underlying mechanism of customers' satisfaction in services through innovation is still challenging. Innovation is considered successful when customer's satisfaction is achieved. Telecom sector provides its customers with variety of choices through innovation which add value in the mind of customers (Mahmoud and Hinson, 2017). Failure of innovations creates an issue; solution of it leads to wave of importance of customer value creation which ultimately directs to customer satisfaction. Being having crucial place in the marketing thoughts CVC (customer value creation) is still nascent. Companies fail to create value due to many reasons. If value is not created then innovation is considered useless. This study attempts to fill the gap by studying the value creation process through service innovation. This study is going to focus on interactive and supportive characteristic of service innovation and its impacts on customers' satisfaction. By applying this model on telecom sector of Saudi Arabia, it aims to understand that how supportive and interactive antecedents of service innovation help to develop customers' satisfaction and creates value which mediates the relationship.

\subsection{Research Questions}

This study attempts to answers the following research questions.

1) Does Supportive Service innovation is related to interactive service innovation?

2) What is the impact of interactive service innovation on customer satisfaction?

3) What is the impact of supportive service innovation on customer satisfaction?

4) Does relationship between interactive service innovation and customer satisfaction mediate by customer value creation?

5) Does relationship between supportive service innovation and customer satisfaction mediate by customer value creation?

\subsection{Research Objectives}

1) To identify the relationship between Supportive Service innovation and interactive service innovation.

2) To measure the impact of interactive service innovation on customer satisfaction.

3) To measure the impact of supportive service innovation on customer satisfaction

4) To measure the mediating role of customer value creation between interactive service innovation and customer satisfaction.

5) To measure the mediating role of customer value creation between supportive service innovation and customer satisfaction.

\subsection{Literature Review}

\subsubsection{Service Innovation}

Several themes ideas are emerged from the innovation phenomenon. Innovation accelerates the growth and performance of company. Innovation is divided into different categories on the basis of nature of innovation for both product and service (Wang et al., 2015). A classification of service improvements is given by a few writers with the aid of which service innovation are grouped into radical innovation (for example predominant innovations, begin-up companies, and new services for the market that are currently being presented) and incremental innovation (e.g., carrier line extensions, carrier enhancements, and fashion adjustments) (Johnson et al., 2000). According to Wang et al. (2015) provider innovation exists in three modes, along with the enterprise version, carrier product, and provider procedure. In earlier studies service innovation conceptualized and investigated from three views, based on previous works (Edvardsson \& Olsson, 1996; Salunke et al., 2013). These views are assimilation, demarcation and synthesis (Combs \& Miles, 2000; Witell et al., 2016; Snyder et al., 2016). New technologies are introduced in service innovation and considered as extension of product innovation (Droege, Hildebrand, \& Forcada, 2009), from an assimilation attitude; the concept of service innovation is explained with goods-dominant logic (GDL) (Vargo \& Lusch, 2004), on this angle. The spell, in which value-in-alternate used as value is created by a firm and customers; its passive receiver. Service is developed in such a way that value of service is rooted in its unit of output or price in trade. (Edvardsson \& Olson ,1996), as it is visible. It is argued by the advocators of this angle that the ideas evolved in GDL may be applied without problems in provider contexts due to the similarities between items and offerings and the offerings zone becoming technology-extensive (Gallouj and Savona, 2009). For this reason, service innovation on this angle by and large makes a specialty of technical service innovation; it leads to technical catalog of products (Miozo \& Soetie, 2001). Service innovation is labelled as an incremental and discontinuous dichotomy by Olsen and Sallis (2006). The distinctiveness of service sectors 
is acknowledged by the demarcation attitude and non-technological varieties of innovation are focused (Sundbo et al., 2007). Scholars who followed this perspective they argued that it should be presented separately from GDL and it should be focused to make it unique (Fitzsimmons \& Fitzsimmons, 2000) due to the specific characteristics of offerings (for example intangibility, heterogeneity, perishability and inseparability). More overly, service innovation is characterized as less radical and mostly incremental and informal (Edvardsson and Tronvoll, 2013). The development of latest procedures or strategies are emphasized by the service innovation in this angle, the necessity for client integration and involvement of business data and non-technical elements which includes frontline personnel' abilities (Hipp \& Grupp, 2005; Nijssen et al., 2006).

Ultimately, a synthesis attitude posits that each one improvements is service innovation (Hsieh, Chiu, Wei, Rebecca, \& Cheng; 2013), theoretical foundation of service innovation is sufficiently vast to cover each kind of business. According to this point of view service innovation is examined through SDL lens. Through which service innovation can be seen as a fresh and valuable "procedure of utility of specialized competences (information and talents) deeds, tactics, and performances for the benefit of every other entity or the entity itself" A specialty of the value proposition is made by service innovation as a platform offered by means of service organization to customers and value is created. (Skålén et al., 2015). We have defined the service innovation as value creation process by players of service structures; value is created for themselves and others, to augments the well-being of all through better processes. (Barrutia \& Gilsanz, 2013; Edvardsson \& Tronvoll, 2013).

Conventionally interactive and supportive service innovation are considered as a characteristic of all offerings as produced and consumed simultaneously. It is regularly thought by the people that service is supplied in assist of core products. Government, transportation, verbal exchange, finance, hospitality, schooling, retail, computing, and facts services are part of the provider industry. Narrower idea of innovation in interactive and supportive services will be considered for the motive of this paper. Bolton and Saxena-Iyer (2009) characterize interactive services along dimensions: the volume to which the purchaser participates and the volume to which generation is utilized within the creation and shipping of the service. Technology is a device for firms to innovate (Bolton \& Saxena-Iyer, 2009). Incremental and radical innovations are developing quicker by the firms with the rapid development of era. Although development of networks of firms that mutually create and deliver services to customers characterized with the aid of two-way interactions is complimented by the convergence of technology, innovation of this type may be in particular tough. Clients at the moment are capable of co-create and take part in the delivery manner of interactive services (Ja-Shen et al., 2015; Prahalad \& Ramaswamy, 2000). For telecom industries, business support systems (BSS) play a critical role in customer support. Telecommunications provider makes use of BSS to run its purchaser-facing business operations. They're used to assist numerous quit-to-end telecommunication services (e.g., cellphone offerings), collectively with operations assist systems. Consequently, supportive and interactive services turn out to be strategic alternatives in a firm's customer pleasure efforts. Value - creation is allied with interactive and supportive service innovation; value is initiated by firm idea is intended to provoke perceptive, emotional and interactive retorts from customers who interact with the brand new cost proposition or carrier concept (Salunke et al., 2013).

However, Customers of business augment the service innovation (Matsuo, 2006). Customers' feedback often comes by means of identifying and realizing the competence value which is provided by new offerings through new services (Michel et al., 2008). Interactive service innovation is defined as "the degree to which a firm adjustments its service offerings and service delivery and customization adjustments". The indirect value-creating adjustments at the returned give up, that guide the brand new value proposition is referred to supportive provider innovation (Salunke et al., 2013). Many types of assistive structures, which include recommendation agents, comparison matrices, ordering and ranking equipment, are mentioned in the literature. This equipment is valuable for online buyers due to the utilization of shelf area and the dearth of bodily interaction among clients, customers, merchandise and the sale pressure (Häubl \& Trifts, 2000). The assistive cause of a firm refers back to the degree of care and guide furnished by way of the firm to fulfill its clients' needs as pointed out by Poddar, Doonthu and Wei (2009). It is evident from such argument that the time period "assistive rationale" has a similar meaning to supportive service in this study. A fresh service offering must be all-in-one; it should provide an adequate behind the scenes configuration to aid the new value proposition with which the customers interact (Salunke et al., 2013). There is a need to inaugurate a connection between interactive and supportive dimension of service innovation. Because this relation jointly upshot the marketing process (Mahajan, Vakharia, \& Chase; 1994). In the telecommunication industry new features are developed and offered which need high customer interaction through strong support system (a backend process). So it leads to development of connection between supportive and interactive service innovation. As Berry, Zeithaml, and Parasuraman (1985) argued that parting the supportive service innovation from interactive service innovation lead to create problems. Firms sales and quality of service 
are may harmed by this disconnection. Activities of supportive service innovation are not evident to customers; they find it useful through interaction.

\subsubsection{Customer Satisfaction}

Innovation contributes towards value creation process and achieving customer satisfaction. In the field of marketing customers' satisfaction is placed at the top of marketing activity. Companies and marketers main focus is maximizing customers' satisfaction. It gained attention in 1970s and paradigm shift was observed in 1990s; when relationship marketing was given importance to achieve satisfaction (Hennig-Thurau \& Klee, 1997). Customer satisfaction is result of different marketing and service activity. Expectation Disconfirmation theory is used to explain the process of customers' satisfaction.

\subsubsection{Expectation Disconfirmation Theory (EDT)}

According to this theory satisfaction is function of expectations. Satisfaction is defined as extent to which a person is considered happy and gratified with the use of product, service or innovation after having the direct experience. EDT is based on Dissonance theory according to which difference between reality and cognition of individual influence; the behaviour of individual (Festinger, 1957). On the basis of this theory, EDT measures customer satisfaction as the difference between their expectations and performance of product, service or technology (Oliver, 1980). According to EDT model customers have some expectations with any offering in the market before using it and evaluate the product on the basis of these expectations. Customer satisfaction emerged when customers compare the performance and pre-purchased expectations. It may result in satisfaction, dis-satisfaction or neutral feelings.

\subsubsection{Service Innovation and Customer Satisfaction}

There has been a tremendous quantity of studies investigating the character of delight and its relationship to other constructs, for example service quality. It is typically acknowledged that service quality impacts contentment directly. Therefore, if service quality is progressed, satisfaction could be progressed (Soutar, 2001). Dentition of customer satisfaction for this research is adopted from (Anderson \& Narus, 1990) according to which that customer satisfaction is evaluation of firms' relationship with its customers from all aspects which yield positive sentimental state. In a high-tech provider enterprise, Successful innovation is important for a firm's overall performance (Van Riel et al., 2004) especially within the present day fairly competitive environment in which players are trying to live on in a matured market.

It is observed that in hotel business service innovation is observed to have a bigger influence on preference (Victorino et al., 2005) and customer value (Flint et al., 2005). Purchaser contentment is undoubtedly influenced by service innovation in the recreation industry (Yeh \& Fu, 2013). It is argued by Kangis and Rankin (1996) that if purchasers be given interactive services, there will be a change in the way they perform their day to day activities. Video, textual content and audio will be included in such services which will be interactive not only between the user and provider but also with a community of other users and providers. As a customer can also manage decisions and actions without having to leave home, those innovations are occasionally known as armchair offerings. "Assistive reason" is a term developed by Gupta et al. (2009) which means that "buyer's perceptions of the extent to which the online seller exhibits intent, implicitly embedded in task facilitative tools aligned with the buyer's interests, to help the buyer fulfils a specific task on the seller's website" (p. 160). It is founded that impressions of assistive intent develop in customers' minds without any explicit expression of the e-vendor's intents. Furthermore, it is suggested by (Walter et al., 2003) that innovation is undoubtedly associated with general relationship quality (i.e., agree with, pleasure, and dedication). According to Mahmoud, Hinson and Anim (2017) Innovation upsurges the chances of meeting customers' needs and providing a key to company to achieve customer satisfaction.

\subsubsection{Service Innovation and Value Creation}

Value for the firm and customers is created indirectly by this shape of service innovation and is serious to make certain the steadiness of center and assisting services (Martin et al., 1999). Supportive innovation is defined in this research study as the "degree to which a firm challenges its service production, sourcing, and service quality", as followed by the previous study of (Salunke et al., 2013) on supportive service innovation and a study from Shobeiri et al. (2014) about assistive purpose. For a successful operation a link has to be made and bolstered among the value propositions offered by service firm and the underlying guide systems and techniques. The linkage can mutually support the marketing and operation capabilities as it is argued by (Mahajan et al., 1994). Inside the context of the telecom service industry, every time a provider company develops a new feature as part of its services, new exercises are needed that could encompass provisioning of recent assets and abilities devoted to the 
support and innovation of the brand new characteristic through new tasks. In today's aggressive worldwide market, to gain an understanding of the consumer's entire value chain (holistic desires) regarding the current needs and anticipated needs (Slater \& Narver, 1995). The understanding of the buyer's value chain should be used by the companies to combine and match their various products and/or services (service package/bundle), existing services or newly released services should be talked upon, techniques should be adjusted and evolved to supply and hold these offerings (like progressed provider shipping quotes), to encounter the patron's needs with the objective to influence the customers perceived value of the imparting. Service innovations may be seemed as a value creating interest (Slater \& Narver, 1995). A firm's competitive gain, for service providers, is established by the innovating offerings in such way that permits them to serve their purchaser's present and future needs which provides to their perceived value (Kandampully \& Duddy, 1999). Beside, innovation on its very own is of lesser importance, as it's far the value of the innovation as perceived by the purchaser that offers the benefit of the offering (Chapman, Soosy, \& Kandampully., 2002). Tether, Metcalfe and Miller (2001) mentioned that the kingdom of the client's perceptions is typically remodeled by service improvements (De Jong et al., 2003). This has an impact on will upload to the purchaser's perception of the value of the service, as has additionally been suggested in different research (Flint et al., 1997; Kandampully \& Duddy, 1999). When service innovation is viewed as a value growing activity or one which influences/adds to the perceived value of the offering, it becomes vital, because interrelation among service innovation and customer value creation is suggested and emphasized.

\subsubsection{Service Innovation, CVC and CS}

In this study, CS has been described as "a reaction to an evaluation of perceived products or service performance is based completely at the customer's judgments of the value that has been created for them" (Flint et al., 1997). Perceived purchaser value has been defined as "the customer's evaluation of the value that has been created for them via a supplier, given the trade-offs between all applicable blessings and sacrifices in a specific use scenario" (Flint et al., 2002). These definitions are confusing for everyone. They are unique although they have similarities. Comparison of definitions shows, theoretically, perceived customer value as antecedes of CS, because the value judgment comes earlier than the assessment reaction. The theoretical linkage between perceived consumer value and CS have been empirically confirmed because it is proved by numerous service marketing literature, that the CVC idea to be a vital aspect in gaining CS (Zeithaml, 1988; McDougall \& Levesque, 2000; Cronin et al., 2000; Wang \& Ahmed, 2004; Truel \& Serenko, 2006; Hume \& Sullivan Mort, 2008; Kuo et al., 2009). Creation of customer value is a significant driver of CS because when higher levels of value are perceived by consumers in an offering they are likely to feel positive about their consumption experience and purchase decision (Oh, 2000; Zeithaml, 1988). On the basis of literature, a model is presented in fig. 1 which speculates that service innovation act as antecedent of value creation leading to higher satisfaction.

\subsection{Research Hypothesis}

It leads to the development of following hypothesis;

$\mathrm{H}_{1}$ : Supportive Service innovation is related to interactive service innovation.

$\mathrm{H}_{2}$ : Interactive service innovation is positively associated with customers' satisfaction.

$\mathrm{H}_{3}$ : Supportive service innovation is positively associated with customers' satisfaction.

$\mathrm{H}_{4}$ : Interactive service innovation mediates the relationship between supportive service innovation and customer value creation.

$\mathrm{H}_{5}$ : Customer Value creation significantly mediates the relationship between interactive service innovation and customer satisfaction.

$\mathrm{H}_{6}$ : Customer Value creation significantly mediates the relationship between supportive service innovation and customer satisfaction.

\subsection{Theoretical Framework}

On the basis of literature, following model is proposed and tested. Model explains the relationship among the variables. It is developed on the basis of past studies (Thi Ta and Yang, 2018; Mahmoud, Hinson and Anim, 2017). Study focus on understanding the value creation process through service innovation and mediating role of value creation between service innovation and customer satisfaction. Service innovation act as predictor of customers' satisfaction through value creation. Literature supports this relationship. 


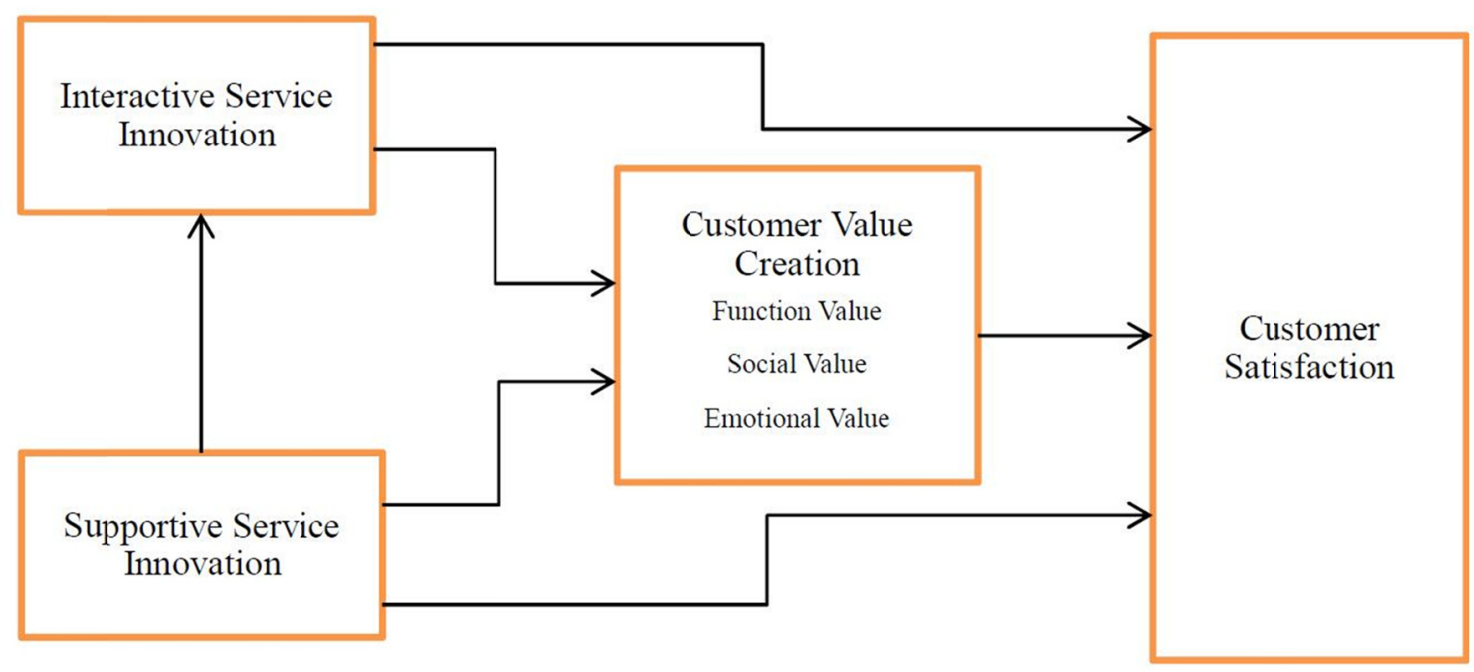

Figure 1. Conceptual model

\section{Research Methodology}

\subsection{Study Design}

To achieve the desire results the study is conducted in sister cities of Saudi Arabia. Primary data is collected to study Impact of service Innovation On customer's satisfaction of telecom sector; value creation as mediator is tested. Cross-sectional time horizon has been selected for this research and the setting is non-contrived. A Quantitative correlational design is chosen. Individual unit of analysis is selected for the study. The statistical test has performed in this study are correlation, regression and mediation analysis.

\subsection{Population}

The population of this study includes mobile users of sister cities in Saudi Arabia. As the research area is Riyadh/Jeddah. Therefore, population from sister cities is included, that is Riyadh and Jeddah.

\subsection{Sample Size}

In this study primary data was collected through questionnaire survey. This study consists of 4 demographic questions and 25 observed questions using likert scale of 5 . The sample size depends upon the number of observed questions, so taking 10 observations per observed question the minimum sample should be 250 (Kline, 2004).

\subsection{Sampling Technique}

To collect data convenient sampling technique is used. It is type of non-probability sampling in which data is collected from those respondents who are conveniently available. It is not possible to collect the data from all the residents of Riyadh/Jeddah. Convenient sampling technique is very beneficial as it is time saving and cost saving.

\subsection{Variable Measures}

Structured questionnaire has been used as a research tool. The questionnaire is adopted from different sources. All the Variables are measured at 5 point Likert scale. Interactive Service Innovation is measured using 4 items; e.g. "The mode by which the Telecom provider interact with me" adopted from (Salunke et al., 2013) study also used by (Thi TA \& Yang, 2018) study.

Supportive service innovation is measured by using 4 item scale e.g. "The ways in which the Telecom provider takes care of its own customers and myself are innovative" adopted from (Salunke et al., 2013) study also used by (Thi TA \& Yang, 2018) study.

Value creation is measured by using 9 item scale adopted from (Mahmoud, Hinson, \& Anim, 2017). 3 items to measure financial value e.g. "My mobile service is worth the price I pay", 3 items to measure emotional value e.g. "My mobile service usage makes me feel good" and 3 items to measure social value e.g. "My mobile service usage 
makes a good impression in my social group". Customer Satisfaction is measured by using 4 items scale adopted from (Thi TA \& Yang, 2018) study.

\subsection{Statistical Technique}

In this research statistical package for Smart PLS3 is used to analyze the data for sample description, description statistics is used. Regression, mediation and correlation analysis would use to explore data.

\section{Results}

\subsection{Data Analysis}

Data analysis has been done using SmartPLS3. Data is collected from workers and students of different universities in sister cities (Riyadh/Jeddah) of Saudi Arabia. Demographic profile of respondents shows $46 \%$ of respondents were male and $54 \%$ were female. Further analysis reveals that mostly respondents belonged to age group 25 and below i.e. $47 \%$, whereas remaining $53 \%$ belongs to other age groups. While $59 \%$ of respondents are working and $41 \%$ are students. Mostly respondents use Mobile mobile service their percentage is $42 \%$. While Etihad Atheeb and Bravo users are 21\%. Zain users are very low $17 \%$.

\subsubsection{Reliability Analysis}

Reliability is the measure of internal consistency of data. According to Sekaran (2000) reliability is a degree to which a questionnaire provide stable and consistent results over the time. Cronbach's alpha is one of statistical tools used for measuring the internal reliability of scale. It enables researcher to analyze its scale and interpret data in a better way. Cronbach alpha, reliabilities less than 0.6 are deemed poor, less than 0.5 are not acceptable while those with ranges of 0.7 are acceptable. Whereas normal value of reliability lie between $0.6-1$. The result of analysis reveals that data is reliable as values for all variable are greater than 0.7. Cronbach Alpha values for Customer satisfaction is 0.78 , for Customer value creation is 0.86 , for interactive service innovation is 0.78 and for supportive service innovation is 0.829 . As all Alpha values lies in between 0.7 to 1 , as shown in Table 1 . So data is considered reliable.

Table 1. Reliability analysis

\begin{tabular}{ll}
\hline Variables & Cronbach's Alpha \\
\hline Customer Satisfaction & 0.783 \\
Customer Value Creation & 0.861 \\
Interactive Service Innovation & 0.782 \\
Supportive Service Innovation & 0.829 \\
\hline
\end{tabular}

\subsubsection{Validity Analysis}

Validity of instrument was measured through different criteria. Mostly scholar used Fornell-Larcker criterion to assess the validity of construct. It is reliable measure of validity. But while measuring validity using smart PLS3 then this criterion is not used. As some other scholar suggests that Fornell-Larcker criterion is not good measure of discriminant validity in SmartPLS3 (Henseler, Ringle, \& Sarstedt, 2015). So, when measuring validity using smartPLS3 another measure of validity is used. Heterotrait- Monotrait ratio of correlation is is used to measure validity. Henseler, Ringle and Sarstedt (2015) describe this measure as more accurate measure of validity as compared to previous one. It value should be less than 0.9.

Another criterion is Cross loading of variable shows that they are discriminant of each other's. Indicators are having greater loading value for construct of interest (construct which is supposed to be measured by indicators); as compared to other constructs of model. Value of HTMT is less than 0.9 as shown in table which means that discriminant validity is established as shown in Table 2.

Table 2. Validity analysis

\begin{tabular}{|c|c|c|c|c|}
\hline \multicolumn{2}{|c|}{$\begin{array}{l}\text { Discriminant Validity } \\
\text { Heterotrait- Monotrait }\end{array}$} & $\mathrm{CVC}$ & INTSI & SPSI \\
\hline \multicolumn{5}{|l|}{$\mathrm{CS}$} \\
\hline CVC & 0.748 & & & \\
\hline INTSI & 0.578 & 0.595 & & \\
\hline SPSI & 0.680 & 0.683 & 0.714 & \\
\hline
\end{tabular}




\subsubsection{Measurement of Model Fit}

While using smart PLS model fitness could be checked through following measures.

SRMR, NFI, Exact fit criteria d_ULS and d_G, $\mathrm{Chi}^{2}$, RMS_theta

To check the model fitness conventionally accepted values were used. "The SRMR is defined as the difference between the observed correlation and the model implied correlation matrix." So, regular magnitude of inconsistencies could be measure between actual and predicted correlation. It is an absolute measure of (model) fit criterion.

A value less than 0.10 or of 0.08 (in a more conservative version; see Hu and Bentler, 1999) are considered a good fit. Henseler et al. (2014) describe the SRMR as a "goodness of fit measure" for PLS-SEM that can be used to avoid model misspecification. SRMR (Standardized Root Mean Square Residual) $<0.08$ is considered acceptable (Hu \& Bentler, 1999).

Normal Fit Index is defined as " 1 minus the $\mathrm{Chi}^{2}$ value of the proposed model divided by the $\mathrm{Chi}^{2}$ values of the null model. Consequently, the NFI results in values between 0 and 1 . The closer the NFI to 1 , the better the fit. NFI values above 0.9 usually represent acceptable fit". (NFI) $>0.9$ is considered acceptable. Model is considered fit as SRMR value is 0.000 and NFI value is 1 which is in acceptable range as shown in Table 3.

Table 3. Measurement of model fit

\begin{tabular}{ll}
\hline Model Fit & \\
\hline & Estimated Value \\
SRMR & 0.000 \\
NFI & 1.000 \\
\hline
\end{tabular}

\subsubsection{Correlation}

Correlation is conducted to study the relationship between the variables. It ranges for +1 to -1.0 correlations mean that there is no relationship between the variables. +1 one shows highly positive correlation and -1 shows highly negative correlation between the variables. In this study the correlation results show that correlation for mostly variables is significant at $99 \%$ confidence interval. Interactive service innovation and supportive innovation have high correlation which is significant $99 \%$ level of confidence interval. While interactive service innovation is positively correlated with customer value creation and customer satisfaction and it is significant at $99 \%$ level of confidence interval. Supportive service innovation is highly correlated with customer value creation and customer satisfaction with the value 0.696 and 698 respectively; significant at $99 \%$ level of confidence interval. Customer satisfaction and customer value creation both are highly correlated $(0.750)$ and significant at $99 \%$ level of confidence interval. All the variables have value less than 0.8 , hence all are considered separate construct.

Table 4. Correlation

\begin{tabular}{lllll}
\hline & INTSI & SPSI & CVC & CS \\
\hline INTSI & 1 & & & \\
SPSI & $0.0 .715^{* *}$ & 1 & & \\
CVC & $0.0 .578^{* *}$ & $0.0 .696^{* *}$ & 1 & \\
CS & $0.571^{* *}$ & $0.0 .684^{* *}$ & $0.750^{* *}$ & 1 \\
\hline
\end{tabular}

Note. ${ }^{* *}$ Correlation is significant at $0.01(2$-tailed) $*$ Correlation is significant at 0.05 (2-talied).

\subsubsection{Second Order Measurement Model}

This study models one second-order construct, namely customer value creation and measurement model has assessed. Outer loading and reliability is assessed for model. It lies in acceptable range. Model fit also reveals that model is good for measurement.

\subsubsection{The Structural Model}

Figure 2 shows the structural model; it is constructed to test the hypothesis of this study which is developed to test the theoretical frame work. R-square value shows that supportive innovation predicts $51 \%$ interactive service innovation. Customer value creation is $49 \%$ predicted by interactive service innovation and supportive service innovation. While customer satisfaction value of R-square is 0.61 . Path coefficients are assessed on the bases of 
magnitude and signs. Supportive service innovation is significantly related to interactive service innovation $(b=0.71, p<0.01)$ which means that supportive service innovation is related to interactive service innovation, so $\mathrm{H} 1$ is accepted. Customer satisfaction is predicted by interactive service innovation ( $b=0.075, p>0.01)$. $P$ value is not less than $0.05 \%$ level of confidence interval. It should be less than $0.05 \%$. So it is insignificant and $\mathrm{H} 2$ is not supported. Supportive service innovation predicts customer satisfaction $(b=0.27, p<0.01) ; \mathrm{H3}$ is accepted at $99 \%$ level of confidence interval.

Further path analysis shows that interactive service innovation positively related to customer value creation $(b=0.218, p<0.01)$. Supportive service innovation predicts customer value creation positively $(b=0.528, p<0.01)$. Finally, customer value creation predicts customer satisfaction significantly at $99 \%$ level of confidence interval. $(b=0.516, p, 0.01)$.

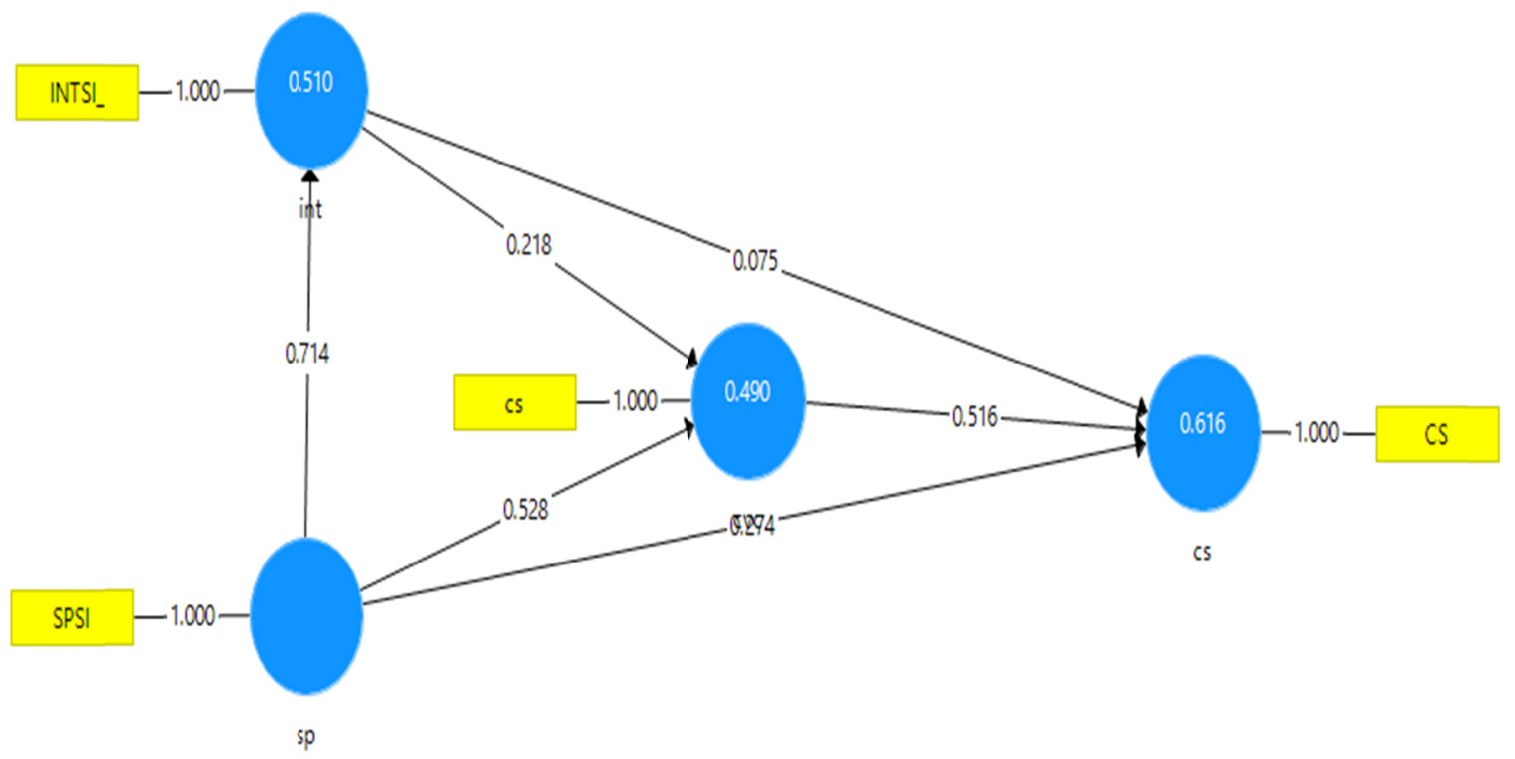

Figure 2. Structural model

\subsubsection{Test for Mediation}

For mediation analysis second-order construct model is used as single variable combining three dimension of customer value creation. Customer value creation is tested as mediator between interactive service innovation and customer satisfaction; supportive service innovation and customer satisfaction. Indirect effects show that relationship between interactive service innovation and customer satisfaction is mediated by customer value creation; $b=0.111$ which is significant at $95 \%$ level of significant. Interactive service innovation brings $11 \%$ change in customer satisfaction through customer value creation. Though the relationship between interactive service innovation and customer satisfaction is not supported. As shown in Fig.3. But modern approaches recommend using sobel test and boosting trapping technique to check the mediation in such cases. So, sobel test bhhis conducted which shows $b=0.3620$, which is significant at $95 \%$ level of confidence interval. Indirect effect of supportive service innovation and customer satisfaction by customer value creation is significant at $95 \%$ level of significant and $b=0.40$. Which shows that one unit change in supportive service innovation brings $40 \%$ change in customer satisfaction through customer value creation. Indirect effect of supportive service innovation is greater than interactive service innovation. The relationship between interactive service innovation and customer satisfaction is fully mediated by customer value creation. While there exists partial mediation between the relationship of supportive service innovation and satisfaction.

A specific path analysis shows that relationship between supportive service innovation and customer value creation is mediated by interactive service innovation. Because interactive service innovation is associated with supportive service innovation. Mediation relationship is significant at $95 \%$ level of confidence interval with coefficient value of 0.1555 . So $\mathrm{H} 4$ is accepted. 


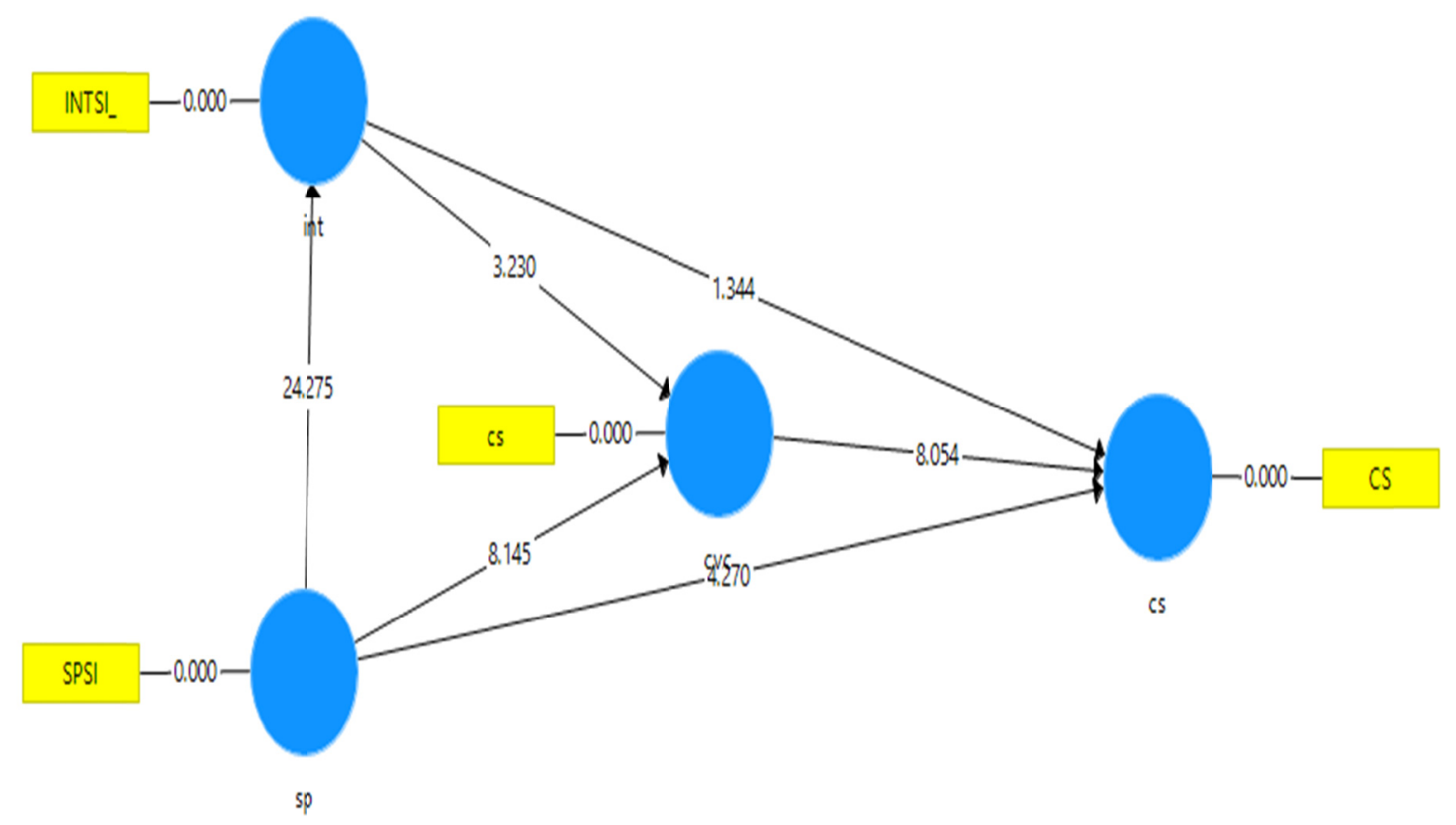

Figure 3. Second-order construct model

\subsubsection{Summary of Results}

Table 5. Hypotheses testing

\begin{tabular}{|c|c|c|}
\hline Hypothesis & Result & Reason \\
\hline H1: Supportive Service innovation is related to interactive service innovation. & Accepted & Significant \\
\hline H2: Interactive service innovation is positively associated with customers' satisfaction. & Not Accepted & In Significant \\
\hline H3: Supportive service innovation is positively associated with customers' satisfaction. & Accepted & Significant \\
\hline $\begin{array}{l}\mathbf{H}_{4} \text { : Interactive service innovation mediates the relationship between supportive service } \\
\text { innovation and customer value creation. }\end{array}$ & Accepted & Significant \\
\hline $\begin{array}{l}\text { H5: Value creation significantly mediates the relationship between interactive service } \\
\text { innovation and customer satisfaction. }\end{array}$ & Accepted & Significant \\
\hline $\begin{array}{l}\text { H6: Value creation significantly mediates the relationship between supportive service } \\
\text { innovation and customer satisfaction. }\end{array}$ & Accepted & Significant \\
\hline
\end{tabular}

\section{Discussion and Conclusion}

\subsection{Discussion}

The motive of this research is to find out the affinity between the antecedents of service innovation and customer satisfaction. It explores that whether the interactive and supportive service innovation is associated with customer satisfaction or not? The results of study depict that significant relationship exist between supportive service innovation and customer satisfaction. While interactive service innovation does not have impact on customer satisfaction alone. That's hypothesis $\mathrm{H} 2$ not accepted. But when it is with linked supportive service innovation then results are significant; which means that interactive service innovation does not predict customer satisfaction when it is not connected with supportive service innovation. As in past researches this relation was found to be very weak as compared to supportive service innovation. (Thi-TA \&Yang, 2018) while relationship of supportive service innovation with customer satisfaction is consistent with previous studies (Thi-TA \&Yang, 2018).

Additionally, this study intended to measure the mediating role of customer value creation between the interactive service innovation, supportive innovation and customer satisfaction. The results support the hypotheses which are proposed. Results suggest that supportive service innovation and customer satisfaction is mediated by customer value creation. This result is consistent with the previous study of (Mahmoud, Hinson, \& Anim, 2017); in which customer value creation is tested as mediator between other dimensions of service innovation and customer 
satisfaction. As in this paper assimilation perspective of service innovation is adopted, according to which all innovations are service innovations. That is the reason behind testing the customer value creation as mediator between interactive and supportive service innovation and customers' satisfaction. Test results proved the hypotheses and mediation is established. So, this study has proved that when innovations are in such a way which support their customers and interact with them, value is created by customers and ultimately it leads to satisfied behaviour of patrons.

\subsection{Conclusion}

The study is conducted to find out the relationship between service innovation dimensions (i.e. interactive and supportive) and customer satisfaction; and mediating role of customer value creation. The results of study publicized the mediation relation of customer value creation among the dimensions of service innovation and customers' satisfaction. Direct impact of interactive service innovation is not supported in the study when it is not linked with supportive service innovation. But when it is linked with supportive service innovation it acts as significant predictor of customer value creation. Because support leads to interaction; because when companies are supportive then they will interact with their customers.

Furthermore, data analyses show that even if there is direct relationship, it isn't significant; but mediation exists between interactive service innovation and customer satisfaction. Mediation relationship is found significant between supportive service innovation and customer satisfaction. Specific mediation results are also proved significant as they are not part of study i.e. sequential mediation through interactive service innovation and customer value creation between supportive service innovation and customer satisfaction. This relation was not under the part of this study. But it leads to the conductance of more researches in this way in future. The findings of research are helpful for future research, and provide marketers the key to gain more customers satisfaction through customer value creation.

\subsection{Limitations of Study}

There are few limitations of the study that have been faced while conducting the research process. First of all, the sample size of this research is very small (i.e.227) and it is cross sectional study. Secondly, due to time constraints, convenience sampling is used to obtain consumers' responses which enhance the biasness and produced narrow results.

Another limitation of this, data has been collected only from sister cities, for that reason generalizability of study would not be very high. Other factor also has impact on Customer satisfaction i.e. product performance, marketing innovation, etc. we're not studied in this study.

\subsection{Practical Implications}

The result of this study indicates that service innovation paly important in consumers' satisfaction. One of two dimensions of service innovation has positive customer satisfaction. This study helps to understand the role of supportive and interactive service innovation in value creation and ultimately customer satisfaction. Customer perceives value of innovation when it is supportive. It means company should focus on developing innovative business support strategies, to interact with customers. Another thing is that mostly respondents are using Mobile i.e. $42 \%$. Other telecom companies should focus on this aspect that why it considered as more supportive as compared to them. It enables the managers to understand the consumer behaviour on which future strategies could be made.

\subsection{Future Directions}

Some future research directions are provided to overcome the limitations of this study in order to explore present relation more elaborately. In future further research could be done by expanding the sample size to other cities. It is good to conduct a longitudinal study to check the cause and effect relationship of variables.

Moreover, research could be conducted to check the impact of other variables along with interactive and supportive innovation to check the combined effect. Other factor also has impact on customer satisfaction i.e. marketing innovation, services innovation, etc. should be considered for future research. Furthermore, this study analyzes the role of value creation as mediator future research should focus on value co-creation process through customer participation. As value co-creation is very emerging concept which should be focused in future.

\section{References}

Alam, I. (2006). Service innovation strategy and process: A cross-national comparative analysis. International Marketing Review, 23(3), 234-254. https://doi.org/10.1108/02651330610670433

Anderson, J. C., \& Narus, J. A. (1990). A model of distributor firm and manufacturer firm working partnership. 
Journal of Marketing, 54, 42-58. https://doi.org/10.2307/1252172

Barrutia, J. M., \& Gilsanz, A. (2013). Electronic service quality and value: do consumer knowledge-related resources matter? Journal of Service Research, 16(2), 231-246. https://doi.org/10.1177/1094670512468294

Berry, L. L., Zeithaml, V. A., \& Parasuraman, A. (1985). Quality counts in services, too. Business Horizons, 28(3), 44-52. https://doi.org/10.1016/0007-6813(85)90008-4

Bolton, R., \& Saxena-Iyer, S. (2009). Interactive services: A framework, synthesis and research directions. Journal of Interactive Marketing, 23(1), 91-104. https://doi.org/10.1016/j.intmar.2008.11.002

Boone, T. (2000). Exploring the Link between Product and Process Innovation in Services, New Service Development. Thousand Oaks, CA: Sage.

Chapman, R. L., Soosay, C., \& Kandampully, J. (2002). Innovation in logistic services and the new business model: a conceptual framework. Managing Service Quality: An International Journal, 12(6), 358-371. https://doi.org/10.1108/09604520210451849

Chen, J. S., Kerr, D., Tsang, S. S., \& Sung, Y. C. (2015). Co-production of service innovations through dynamic capability enhancement. The Service Industries Journal, 35(1-2), 96-114. https://doi.org/10.1080/02642069.2014.979405

Chen, J. S., Tsou, H. T., \& Huang, A. Y. (2009). Service delivery innovation antecedents and impact on firm performance. Journal of Service Research, 12(1), 36-55. https://doi.org/10.1177/1094670509338619

Christensen, C., Horn, M., Michael, B., Caldera, L., \& Soares, L. (2011). Disrupting College: How Disruptive Innovation Can Deliver Quality and Affordability to Postsecondary Education. Innosight Institute.

Combs, R., \& Miles, I. (2000). Innovation, measurement and services: The new problematique. In Innovation Systems in the Service Economy, Economics of Science. Technology and Innovation, 18, 85-103.

Cronin, J. J., Brady, M. K., \& Hult, G. T. M. (2000). Assessing the effects of quality, value, and customer satisfaction on consumer behavioral intentions in service environments. Journal of Retailing, 76(2), 193-218. https://doi.org/10.1016/S0022-4359(00)00028-2

Danjum, I., \& Rasli, A. (2012). Imperatives of service innovation and service quality for customer satisfaction: Perspective on higher education. Procedia-Social and Behavioral Sciences, 40, 347-352. https://doi.org/10.1016/j.sbspro.2012.03.198

De Jong, J. P., Bruins, A., Dolfsma, W., \& Meijaard, J. (2003). Innovation in service firms explored: what, how and why. Business and Policy Research (EIM), Zoetermeer.

Droege, H, Hildebrand, D., \& Forcada, H. (2009). Innovation in services: Present findings, and future pathways. Journal of Service Management, 20(2), 131-155. https://doi.org/10.1108/09564230910952744

Edvardsson, B., \& Tronvoll, B. (2013). A new conceptualization of service innovation grounded in SD logic and service systems. International Journal of Quality and Service Sciences, 5(1), 19-31. https://doi.org/10.1108/17566691311316220

Edvardsson, K., \& Olsson, J. (1996). Key concepts for new service development. Service Industries Journal, 16(2), 140-164. https://doi.org/10.1080/02642069600000019

Festinger, L. (1957). A theory of cognitive dissonance. Evanston: Row, Peterson.

Fitzsimmons, J. A., \& Fitzsimmons, M. J. (2000). New Service Development: Creating Memorable Experiences. Thousand Oaks, CA: Sage.

Flint, D. J., Larsson, E., Gammelgaard, B., \& Mentzer, J. T. (2005). Logistics innovation: A customer value-oriented social process. Journal of Business Logistics, 26(1), 113-147. https://doi.org/10.1002/j.2158-1592.2005.tb00196.x

Flint, D. J., Woodruff, R. B., \& Gardial, S. F. (1997). Customer value change in industrial marketing relationships: a call for new strategies and research. Industrial Marketing Management, 26(2), 163-175. https://doi.org/10.1016/S0019-8501(96)00112-5

Flint, D. J., Woodruff, R. B., \& Gardial, S. F. (2002). Exploring the phenomenon of customers' desired value change in a business-to-business context. Journal of Marketing, 66(4), 102-117. https://doi.org/10.1509/jmkg.66.4.102.18517

Gallouj, F., \& Savona, M. (2009). Innovation in services: a review of the debate and a research agenda. Journal 
of Evolutionary Economics, 19(2), 149-172. https://doi.org/10.1007/s00191-008-0126-4

Gupta, P., Yadav, M. S., \& Varadarajan, R. (2009). How task-facilitative interactive tools foster buyers' trust in online retailers: A process view of trust development in the electronic marketplace. Journal of Retailing, 85(2), 159-176. https://doi.org/10.1016/j.jretai.2009.02.001

Häubl, G., \& Trifts, V. (2000). Consumer decision making in online shopping environments: The effects of interactive decision aids. Marketing Science, 19(1), 4-21. https://doi.org/10.1287/mksc.19.1.4.15178

Hennig-Thurau, T., \& Alexander Klee, A. (1997). The Impact of Customer Satisfaction and Relationship Quality on Customer Retention: A Critical Reassessment and Model Development. Psychology \& Marketing, 14(8), 737-764. https://doi.org/10.1002/(SICI)1520-6793(199712)14:8<737::AID-MAR2>3.0.CO;2-F

Hipp, C., \& Grupp, H. (2005). Innovation in the service sector: The demand for service specific innovation measurement concepts and typologies. Research Policy, 34(4), 517-535. https://doi.org/10.1016/j.respol.2005.03.002

Hsieh, J. K., Chiu, H. C., Wei, C. P., Rebecca, Y. H., \& Cheng, Y. C. (2013). A practical perspective on the classification of service innovations. Journal of Services Marketing, 27(5), 371-384. https://doi.org/10.1108/JSM-10-2011-0159

Hu, L., \& Bentler, P. M. (1999). Cutoff criteria for fit indexes in covariance structure analysis: Conventional criteria versus new alternatives. Structural Equation Modeling, 6, 1-55. https://doi.org/10.1080/10705519909540118

Huang, K. H. (2011). A comparative study to classify ICT developments by economies. Journal of Business Research, 64(11), 1174-1177. https://doi.org/10.1016/j.jbusres.2011.06.018

Hume, M., \& Sullivan Mort, G. (2008). Satisfaction in performing arts: the role of value? European Journal of Marketing, 42(3/4), 311-326. https://doi.org/10.1108/03090560810852959

Ja-Shen, C., Kerr, D., Tsang, S. S., \& Sung, Y. C. (2015). Co-production of service innovations through dynamic capability enhancement. The Service Industries Journal, 35(1-2), 96-114. https://doi.org/10.1080/02642069.2014.979405

Johnson, S. P., Menor, L. J., Roth, A. V., \& Chase, R. B. (2000). A critical evaluation of the new service development process. New service development: Creating memorable experiences, 1-32. London: Sage Publication.

Jörg Henseler, J., Ringle, M. C., \& Marko Sarstedt, M. (2015). A new criterion for assessing discriminant validity in variance-based structural equation modeling. $J$. of the Acad. Mark. Sci., 43, 115-135. https://doi.org/10.1007/s11747-014-0403-8

Kandampully, J., \& Duddy, R. (1999). Competitive advantage through anticipation, innovation and relationships. Management Decision, 37(1), 51-56. https://doi.org/10.1108/00251749910252021

Kangis, P., \& Rankin, K. (1996). Interactive services: How to identify and target the new markets. Journal of Marketing Practice: Applied Marketing Science, 2(3), 44-67. https://doi.org/10.1108/EUM0000000004298

Kline, R. B. (2004). Beyond significance testing: Reforming data analysis methods in behavioral research.

Kuo, Y. F., Wu, C. M., \& Deng, W. J. (2009). The relationships among service quality, perceived value, customer satisfaction, and post-purchased intention in mobile value-added services. Computers in Human Behavior, 25(4), 887-896. https://doi.org/10.1016/j.chb.2009.03.003

Mahajan, J. A., Vakharia, P. P., \& Chase, R. B. (1994). An exploratory investigation of the interdependence between marketing and operations functions in service firms. International Journal of Research in Marketing, 11(1), 1-15. https://doi.org/10.1016/0167-8116(94)90031-0

Mahmoud, M. A., Hinson, R. E., \& Anim, P. A. (2017). Service innovation and customer satisfaction: the role of customer value creation. European Journal of Innovation Management.

Martin, C. R., Horne, D. A., \& Schultz, A. M. (1999). The business-to-business customer in the service innovation process. European Journal of Innovation Management, 2(2), 55-62. https://doi.org/10.1108/14601069910269772

Matsuo, M. (2006). Customer orientation, conflict, and innovativeness in Japanese sales departments. Journal of Business Research, 59(2), 242-250. https://doi.org/10.1016/j.jbusres.2005.06.002

McDougall, G. H., \& Levesque, T. (2000). Customer satisfaction with services: putting perceived value into the 
equation. Journal of Services Marketing, 14(5), 392-410. https://doi.org/10.1108/08876040010340937

Michel, S., Brown, S. W., \& Gallan, A. S. (2008). Service-logic innovations: How to innovate customers, not products. California Management Review, 50(3), 49-65. https://doi.org/10.2307/41166445

Miozo, M., \& Soetie, L. (2001). Internationalization of services: A technological perspective. Technological Forecasting and Social Change, 67(2), 159-185. https://doi.org/10.1016/S0040-1625(00)00091-3

Nijssen, E. J., Hillebrand, B., Vermeulen, P. A., \& Kemp, R. G. (2006). Exploring product and service innovation similarities and differences. International Journal of Research in Marketing, 23(3), 241-251. https://doi.org/10.1016/j.ijresmar.2006.02.001

Oh, H. (2000). The effect to brand class, brand awareness, and price on customer value and behavioral intentions. Journal of Hospitality \& Tourism Research, 24(2), 136-162. https://doi.org/10.1177/109634800002400202

Oliver, R. L. (1980). A cognitive model of the antecedents and consequences of satisfaction decisions. Journal of Marketing Research, 17(4), 460-469. https://doi.org/10.2307/3150499

Olsen, N. V., \& Sallis, J. (2006). Market scanning for new service development. European Journal of Marketing, 40(5/6), 466-484. https://doi.org/10.1108/03090560610657796

Poddar, A., Donthu, N., \& Wei, Y. (2009). Web site customer orientations, Web site quality, and purchase intentions: The role of Web site personality. Journal of Business Research, 62(4), 441-450. https://doi.org/10.1016/j.jbusres.2008.01.036

Prahalad, C. K., \& Ramaswamy, V. (2000). Co-opting customer competence. Harvard Business Review, 78(1), $79-90$.

Salunke, S., Weerawardena, J., \& McColl-Kennedy, J. R. (2013). Competing through service innovation: The role of bricolage and entrepreneurship in project-oriented firms. Journal of Business Research, 66(8), 1085-1097. https://doi.org/10.1016/j.jbusres.2012.03.005

Sekaran, U. (2000). Research Methods for Business: A Skill Business Approach. New York: John Wiley and Sons.

Shobeiri, S., Mazaheri, E., \& Laroche, M. (2014). How customers respond to the assistive intent of an E-retailer? International Journal of Retail \& Distribution Management, 42(5), 369-389. https://doi.org/10.1108/IJRDM-03-2013-0072

Siltaloppi, J., \& Toivonen, M. (2015). Integration of planning and execution in service innovation. The Service Industries Journal, 35(4), 197-216. https://doi.org/10.1080/02642069.2014.990000

Skålén, P. J., Gummerus, C., Koskull, V., \& Magnusson, P. R. (2015). Exploring value propositions and service innovation: A service-dominant logic study. Journal of the Academy of Marketing Science, 43(2), 137-158. https://doi.org/10.1007/s11747-013-0365-2

Slater, S. F., \& Narver, J. C. (1995). Market orientation and the learning organization. Journal of Marketing, 59(3), 63-74. https://doi.org/10.2307/1252120

Snyder, H., Witell, L., Gustafsson, A., Fombelle, P., \& Kristensson, P. (2016). Identifying categories of service innovation: a review and synthesis of the literature. Journal of Business Research, 69(7), 2401-2408. https://doi.org/10.1016/j.jbusres.2016.01.009

Soutar, G. N. (2001). Service quality, customer satisfaction and value: An examination of their relationships. Service Quality Management in Hospitality, Tourism and Leisure, 97-110. New York and London: Routledge.

Sundbo, J., Orfila-Sintes, F., \& Sørensen, F. (2007). The innovative behaviour of tourism firms - Comparative studies of Denmark and Spain. Research Policy, 36(1), 88-106. https://doi.org/10.1016/j.respol.2006.08.004

Tether, B., Metcalfe, J. S., \& Miles, I. (2001). Horndal at Heathrow: Co-operation, learning and innovation: investigating the processes of run way capacity creation at Europe's most congested airports. Centre for Research on Innovation and Competition, University of Manchester.

THI-TA \& Yang. (2018). Exploring the Impacts of Service Innovation on Customer Satisfaction in the Telecom Industry: A Perspective from Interactive and Supportive Service Innovations. International Journal of Innovation Management.

Turel, O., \& Serenko, A. (2006). Satisfaction with mobile services in Canada: an empirical investigation, Telecommunications Policy, 30(5), 314-331. https://doi.org/10.1016/j.telpol.2005.10.003 
Van Riel, A. C. R., Lemmink, J., \& Ouwersloot, H. (2004). High-technology service innovation success: A decision-making perspective. Journal of Product Innovation Management, 21(5), 348-359. https://doi.org/10.1111/j.0737-6782.2004.00087.x

Vargo, S. L., \& Lusch, R. F. (2004). Evolving to a new dominant logic for marketing. Journal of Marketing, 68(1). https://doi.org/10.1509/jmkg.68.1.1.24036

Victorino, L., Verma, R., Plaschka, G., \& Dev, C. (2005). Service innovation and customer choices in the hospitality industry. Managing Service Quality, 15(6), 555-576. https://doi.org/10.1108/09604520510634023

Walter, A., Müller, T. A., Helfert, G., \& Ritter, T. (2003). Functions of industrial supplier relationships and their impact on relationship quality. Industrial Marketing Management, 32(2), 159-169. https://doi.org/10.1016/S0019-8501(02)00230-4

Wang, C. L., \& Ahmed, P. K. (2004). The development and validation of the organizational innovativeness construct using confirmatory factor analysis. European Journal of Innovation Management, 7(4), 303-313. https://doi.org/10.1108/14601060410565056

Wang, Q., Voss, C., Zhao, X., \& Wang, Z. (2015). Modes of service innovation: A typology. Industrial Management \& Data Systems, 115(7), 1358-1382. https://doi.org/10.1108/IMDS-03-2015-0067

Witell, L., Snyder, H., Gustafsson, A., Fombelle, P., \& Kristensson, P. (2016). Defining service innovation: a review and synthesis. Journal of Business Research, 69(8), 2863-2872. https://doi.org/10.1016/j.jbusres.2015.12.055

Yeh, S. P., \& Fu, H. W. (2013). Effects of service innovation on customer satisfaction in recreation industry. International Journal of Applied Mathematics and Statistics, 38(8), 107-116.

Zeithaml, V. A. (1988). Consumer perceptions of price, quality, and value: a means-end model and synthesis of evidence. The Journal of Marketing, 52(3), 2-22. https://doi.org/10.2307/1251446

\section{Appendix A}

\section{Questionnaire}

Responses were measured on five point Likert scale

\section{1= strongly disagree $2=$ Disagree, $3=$ neutral, $4=$ agree, $5=$ Strongly Agree}

\section{Interactive service innovation}

The mode by which telecom provider interact with me is innovative.

The speed in which the services are provided to me is innovative.

The areas of expertise that the telecom provider is engaging is innovative.

The services provided by telecom provider are innovative.

\section{Supportive Service Innovation}

The ways in which the telecom provider takes care of its customers and me are very innovative.

The quality of services provided by this telecom provider is improving.

The processes that the telecom provider solves the complaints from customers are improving

The ways in which the telecom provider's staffs deal with complaints from customers make me comfortable.

\section{Customer Value Creation}

My mobile service usage makes me feel good.

I find my mobile network service engaging.

Using my mobile service gives me pleasure.

Using my mobile service makes me feel relaxed.

Using my mobile service is an enjoyment.

My mobile service is worth the price I pay.

My mobile service is worth the technical quality. 
My mobile service is worth the customer service.

My mobile service offers consistent quality of service.

Using my mobile service is not a financial burden or stress.

My mobile service usage makes a good impression in my social group.

My mobile service usage gives me a sense of belonging.

My mobile service usage helps me to feel accepted by others.

Using my mobile service gives me social approval and recognition.

My mobile service usage improves the way I am perceived by other people.

\section{Customer Satisfaction}

Compared to my ideal, I am satisfied with the performance of telecom provider.

All in all, I am satisfied with this service.

I am not completely satisfied with this provider.

With reference to my expectations, I am very satisfied with this service.

\section{Copyrights}

Copyright for this article is retained by the author, with first publication rights granted to the journal.

This is an open-access article distributed under the terms and conditions of the Creative Commons Attribution license (http://creativecommons.org/licenses/by/4.0/). 